\title{
Positive Effects of Legumes on Soil Organic Carbon Stocks Disappear at High Legume Proportions Across Natural Grasslands in the Pyrenees
}

\author{
Antonio Rodríguez, ${ }^{1,2 *} \odot$ Rosa Maria Canals, ${ }^{3} \odot$ and M.-Teresa Sebastià ${ }^{1,2} \odot$
}

\begin{abstract}
${ }^{1}$ Group GAMES, Department of Horticulture, Botany and Landscaping, School of Agrifood and Forestry Science and Engineering, University of Lleida, Avinguda Alcalde Rovira Roure 191, 25198 Lleida, Spain; ${ }^{2}$ Laboratory of Functional Ecology and Global Change (ECOFUN), Forest Sciences Centre of Catalonia (CTFC), Solsona, Spain; ${ }^{3}$ Grupo Ecología y Medio Ambiente, ISFood Institute, Universidad Pública de Navarra, Campus Arrosadia, Pamplona, Spain
\end{abstract}

\begin{abstract}
Soil is the largest terrestrial carbon pool, making it crucial for climate change mitigation. Soil organic carbon (SOC) is suggested to depend on biodiversity components, but much evidence comes from diversity-function experiments. To disentangle the relationships of plant guild diversity with SOC storage $\left(\mathrm{kg} \mathrm{m}^{-2}\right)$ at broad spatial scales, we applied diversity-interaction models to a regional grassland database $(n=96)$ including wide environmental conditions and management regimes. The questions were: (1) Are the effects of plant guilds on SOC stocks in natural grasslands consistent with those found in experimental systems? (2) Are plant guild effects on SOC stocks independent of each other or do they show interactive-synergistic or
\end{abstract}

Received 8 March 2021; accepted 3 August 2021:

published online 12 September 2021

Supplementary Information: The online version contains supplementary material available at https://doi.org/10.1007/s10021-021-0069 5-9.

Author contributions AR designed the statistical procedure, carried out the statistical analyses and wrote the original draft. RMC was responsible for field monitoring, laboratory analyses and acquisition of information for the database implementation in the Western Pyrenees (Navarre). She reviewed the draft. MTS contributed to the conception, design and development of the PASTUS database. In addition, she ensured funding and coordinated the projects whose data are included in PASTUS. Finally, she contributed to initial modeling supervised the development of the paper and read and reviewed the drafts

*Corresponding author; e-mail: antoniorodriguez@udl.cat antagonistic-effects? (3) Do environmental variables, including abiotic and management, modify guild effects on SOC stocks? Among our most novel results we found, legume effects on grassland SOC vary depending on legume proportion consistently across broad spatial scales. SOC increased with legume proportion up to $7-17 \%$, then decreased. Additionally, these effects were strengthened when grasses and forbs were codominant. Grazing intensity modulated grass proportion effects on SOC, being maximum at relatively high intensities. Interpreting our results in terms of existing contrasted ecological theories, we confirmed at broad spatial scales and under wide-ranging environmental conditions the positive effects of plant guild diversity on SOC, and we showed how legumes exert a keystone effect on SOC in natural grasslands, probably related to their ability to fix inorganic N. Niche complementarity effects were illustrated when codominance of forbs and grasses at optimum legume proportions boosted SOC storage, whereas grass dominance increased SOC stocks at medium-high grazing intensities. These findings can facilitate the preparation of regional and local strategies to ameliorate the soil capacity to absorb carbon. 
Key words: plant guilds; soil organic carbon; climate change; forbs; grasses; management; natural grasslands.

\section{Highlights}

- We analyze plant guilds-soil organic carbon in natural grasslands at broad scales.

- Legume enhancement of soil organic carbon decreased at medium legume proportion threshold.

- The combination of legumes with grasses and forbs boosted SOC storage.

\section{INTRODUCTION}

Soil carbon is highly relevant for climate change mitigation (Canadell and others 2007) because it constitutes the largest carbon pool in terrestrial ecosystems (Batjes 1996). According to current conceptual models, soil carbon sequestration is expected to depend strongly on biodiversity components (Hooper and others 2005; Díaz and others 2007; Hector and Bagchi 2007; Kirwan and others 2009; Suter and others 2015; Connolly and others 2018). However, most evidence comes from diversity-function experiments, which might suggest important underlying mechanisms (Fornara and Tilman 2008; Prommer and others 2020), but do not encompass the whole complexity encountered in real ecosystems. In particular, experimental studies tend to neglect interactions and to reflect only short-term processes; thus, extrapolating their results for real systems could lead to incomplete or misleading conclusions (Yuan and others 2017; Rillig and others 2019). In contrast, evidence about a positive association between soil carbon storage and plant diversity in observational, broad-scale studies is scarce despite some recent attempts (Hollingsworth and others 2008; Manning and others 2015; Wardle 2016; Chen and others 2018).

Although the role of every plant species in the ecosystem may be unique (Wayne and Bazzaz 1991), grouping them into plant guilds provides good summary representations for biodiversityfunction analysis (Sebastià 2007). Plant functional types (PFT) are suites of species that share ecological characteristics and play similar roles in ecosystems (Steneck, 2001; Blondel, 2003). When defined in terms of resource use, they are often called guilds (see Sebastià 2007; and Root 1967 for animals).
Among other biodiversity approaches, plant guilds have been found to be highly relevant for explaining soil carbon content in experiments (Fornara and Tilman 2008; Lange and others 2015). Considering grassland ecosystems, grasses are efficient in terms of light capture because their leaves are at vertical angles (Sebastià 2007; Zhou and others 2016), while the architecture of their roots makes them efficient capturing soil $\mathrm{N}$, among other nutrients. Legumes can have access to symbiotically-fixed atmospheric $\mathrm{N}$ and have recently been found to be more active in terms of $\mathrm{CO}_{2}$ exchange per biomass unit compared with other guilds (Ibanez and others 2020). Nonlegume forbs present a variety of ports and leaf angles, can store high amounts of nutrients in their roots and cannot fix atmospheric N (Schmid and others 2004; Lipowsky and others 2015; Herz and others 2017). Finally, sedges share multiple morphological features with grasses, but often present some differences in their photosynthetic tissues and higher root to shoot ratios (Mou and others 2018). The consideration of sedges as a separate group from grasses was recommended by Onipchenko and others (2012), because of their high nutrient uptake capacity over grasses in that study.

Plant guild effects on soil carbon storage need to be studied at broad scale to understand how they work under different broad-scale abiotic conditions, as is being done for plant taxonomical and functional diversity (Manning and others 2015; Carol Adair and others 2018). Ecologists and modelers need this information to validate conceptual paradigms and generate new hypotheses contributing to the refinement of global mechanistic models. Land managers and policymakers need it to establish priorities for conservation objectives. Grasslands are ideal to study soil organic carbon (SOC)-biodiversity interactions, due to their wide distribution, high SOC stability and biodiversity compared to other ecosystems (Suttie and others 2005; Poeplau and Don 2013; Dengler and others 2014). Taking into consideration that previous studies, carried out at narrower scales, found a crucial but contrasting role of legumes among the plant guilds (e.g., Fornara and Tilman 2008; Lange and others 2014), we aim to answer the following questions:

1. Are the effects of plant guilds on SOC stocks in natural grasslands consistent with those found in experimental systems?

2. Are plant guild effects on SOC stocks independent of each other or do they show interactive-synergistic or antagonistic-effects? 
3. Do environmental variables, including abiotic and management, modify guild effects on SOC stocks?

To answer these questions, we built statistic models of SOC stocks distribution using an extensive database generated from a survey of 96 natural grasslands in the Pyrenees. The database includes a variety of climates; different landscape positions; and a range of grazing management regimes. This environmental heterogeneity is also reflected in the wide variability of plant guild composition (Sebastià 2007; Gómez 2008). We applied the diversity-interaction modeling (DIM) approach (Kirwan and others 2009), which allowed us to separate the identity and interaction effects of plant guilds. This approach consists of testing a series of hypotheses, from the absence of biodiversity effects on SOC to the existence of interaction effects involving both plant guilds and environmental drivers (Kirwan and others 2009; Connolly and others 2013).

\section{MeTHODS}

\section{Study Sites}

The set of data used in this study was extracted from the PASTUS Database (http://ecofun.ctfc.cat/ $? p=3538)$, compiled by the Laboratory of Functional Ecology and Global Change (ECOFUN) of the Forest Sciences Centre of Catalonia (CTFC) and the University of Lleida (UdL). We sourced a wealth of data of 96 grassland patches distributed across the Pyrenees (Figure S1), including topographical, climate, soil, herbage and management variables. The elaboration of the PASTUS Database concerning this study is summarized in Figure S2. The sampled area encompasses a wide variety of temperate and cold-temperate climates with different precipitation conditions, depending on altitude and geographical location, from Mediterranean to continental and Boreo-Alpine environments (de Lamo and Sebastià 2006; Rodríguez and others 2018, 2020). Almost all of the plant species in the grasslands from the PASTUS Database are perennial (Sebastiá and Sebastià 2004), and both plants and environments are highly heterogeneous (Rodríguez and others 2018).

\section{Sampling Design}

Sampling in the PASTUS Database was designed according to a stratified random scheme, where samples were selected at random within strata. This process was undertaken using the ArcMap 10 software (ESRI, Redlands, CA, USA). The basis for randomization was the map of habitats of Catalonia
1:50 000 (Carreras and Diego 2006) for the eastern and central sectors of the Pyrenees; the map of habitats of Madres-Coronat 1:10,000 (Penin 1997) for the northeastern sector; and the land use map of Navarre 1:25,000 (Gobierno de Navarra 2003) for the western sector. Four variables were initially considered for sampling stratification within each sector: altitude (< 1800; 1800-2300; > $2300 \mathrm{~m})$, slope $\left(0-20 ; 20-30 ;>30^{\circ}\right)$, macrotopography (mountain top/south-facing slope; valley bottom/ north-facing slope) and grazer type (sheep; cattle; mixed). Accordingly, we determined a set of homogeneous grassland patches by crossing the stratification variable layers. Grassland patches were then listed by type and arranged within each list randomly to determine sampling priority. At least one to two replicates of each patch type, defined by the stratification variables, were sampled.

In each sampled grassland patch, a $10 \times 10 \mathrm{~m}^{2}$ plot was systematically placed in the middle of each homogeneous grassland patch, including a particular plant community. We collected soil and vegetation samples and assessed environmental variables within each $100 \mathrm{~m}^{2}$ plot (see Rodríguez and others 2018, 2020), for additional details about sampling design). Local environmental variables were assessed inside the $100 \mathrm{~m}^{2}$ plots.

\section{Climate, Topographical and Grazing Drivers}

All the variables included in this study are listed in Table S1. Climate variables were determined from Worldclim 2.0 (Fick and Hijmans 2017). Based on previous modeling of SOC in grasslands in the Pyrenees (Rodríguez and others 2020), we selected mean annual precipitation (MAP) and the intraannual difference of temperature (Temperature Seasonality Index of Sebastià (TSIS); (Debouk and others 2020; Rodríguez and others 2020)), calculated as the difference between mean summer temperature and mean annual temperature.

Topographical variables included slope and macrotopography. Slope was determined in the field by clinometer. Macrotopography included exposed (south- and east-facing slopes, mountain tops) and protected (north- and west-facing slopes, valley bottoms) positions.

Regarding grazing management variables, detailed surveys were carried out among farmers, shepherds and land managers, to complete the initial general information used in the sampling design. We used these data to determine grazing intensity by estimating livestock stocking rates measured as livestock units/ha (LU/ha). We treated 
it as a semiquantitative variable with three categories (Sebastià and others 2008): low $(1:<0.2$ LU/ha), moderate (2: $0.2-0.4 \mathrm{LU} / \mathrm{ha}$ ) and highmoderate (3: up to $0.4 \mathrm{LU} / \mathrm{ha}$ ); a few samples corresponded to abandoned grasslands (0 LU/ha).

\section{Soil Environmental Factors and SOC Stocks}

In each plot, one soil core was extracted with a $5 \times 5 \mathrm{~cm}$ probe at $0-20 \mathrm{~cm}$ soil depth. To determine bulk density, we air-dried and weighed the soil samples: We then sieved each sample to $2 \mathrm{~mm}$ to separate stones and gravels from the fine earth fraction. The fine fraction was sent to the laboratory to determine soil texture, $\mathrm{pH}$ and soil organic carbon (SOC) stocks. Textural classes in the top 10$\mathrm{cm}$ soil layer were determined by the Bouyoucos method (Bouyoucos 1936), and soil pH in the top 10-cm soil layer was measured in water (Solly and others 2014). Total carbon (C) concentration of the fine earth was determined by the elemental autoanalyzer. Soil organic carbon stocks (SOC) in the upper $20-\mathrm{cm}$ soil layer were then estimated taking into account the organic $\mathrm{C}$ concentration in the sample and its bulk density, and subtracting the coarse particle $(>2 \mathrm{~mm}$ ) content, following García-Pausas and others (2007). Hence, we obtained SOC stocks in $\mathrm{kg} \mathrm{m}^{2}$ at a fixed depth of $20 \mathrm{~cm}$. See Rodríguez and others (2020) for further details about SOC sampling and determination.

\section{Plant Guild Proportions}

Plots of $10 \times 10 \mathrm{~m}^{2}$ were established in the middle of homogeneous grassland patches holding a given plant community (Canals and Sebastià 2000; Sebastiá 2004). Aboveground biomass was estimated from herbage harvested in four $50 \times 50 \mathrm{~cm}$ quadrats placed in a $2 \times 2 \mathrm{~m}$ subplot within the $100 \mathrm{~m}^{2}$ plot. Plant guild biomass was determined in one of the four quadrats per plot by hand separation. Four guilds were sorted: C3 grasses, sedges, legumes and non-legume forbs (the latter including some subshrubs), following Sebastià (2007). Guild biomass was then oven-dried at $60^{\circ} \mathrm{C}$ to constant weight.

\section{Diversity-Interaction Models}

To disentangle plant guild effects on SOC, we built a series of models following the diversity-interaction model (DIM) approach (Kirwan and others 2009). We log-transformed SOC (logSOC) using the natural logarithm to prevent a breach of the normality assumption by the residuals of the models (Figure S3).
DIM models were fitted in a four-step process based on equations from Kirwan and others (2009) and Connolly and others (2013). First, we defined a null model; Model 0:

$$
y=b X+\varepsilon
$$

where $\operatorname{logSOC}(y)$ depends on a series of terms including environmental abiotic variables and interactions between them $(X)$, each one affecting $y$ according to its coefficient $b$. The remaining variance of $y$ is provided by model error $\epsilon$. According to this null model, there are no effects of plant diversity, including plant guild proportions, on SOC. We decided to use the geophysical model presented in Rodríguez and others (2020), using data from the same database, as this null model. Although the set of data employed for fitting the two models was not exactly the same because plant guild variables were not measured in all the PASTUS Database samples, this model properly explained a significant amount of the total SOC variance $\left(R_{\text {adj }}^{2}=0.37\right)$ when including only the sites selected for the present study. The model terms of this model (Table 1) were already explained in Rodríguez and others (2020), allowing us to focus on plant guild effects in this work. Additionally, models obtained with the same procedure using only the sites in this work (Appendix) included only MAP, TSIS and clay content, whereas the model from Rodriguez and others (Rodríguez and others 2020) finally used here also included topography and grazing management variables. This is an advantage since the variables of the null model will be used to test interactions with plant guilds in Model 4.

Secondly, we fitted Model 1:

$$
y=\sum_{i=1}^{s} \beta_{i} P_{i}+b X+\varepsilon
$$

which simply consists of the addition of each plant guild proportion $P$ and the estimation of its effect on $y(\beta)$ to the null model. This model assumes that plant guilds affect SOC exclusively by their single (identity) effects, without interactions. Note that these models are similar to a conventional linear model (Legendre and Legendre 1998) but removing the intercept to allow the inclusion of all the plant guild proportions (Connolly and others 2013).

Model 2 (evenness model) assumes that there are interaction effects between plant guilds and that they are the same for all the pairwise plant guild combinations: 
Table 1. Results of the Geophysical Model Presented in Rodríguez and others (2020) for Soil Organic Carbon, Applied to the Dataset Used in this Work $\left(\mathrm{R}_{\text {adj }}^{2}=0.37\right)$.

\begin{tabular}{lllcc}
\hline Model term & Estimate & SE & $t$ value & $p$ value \\
\hline Intercept & -0.54 & 2.13 & -0.25 & 0.80 \\
Environmental drivers & & & & $<.026$ \\
MAP & 0.003 & 0.001 & -0.712 & $0.001^{* * *}$ \\
TSIS & -0.204 & 0.286 & -3.210 & $0.002^{* *}$ \\
Exposed & -3.335 & 1.039 & -3.087 & $0.003^{* *}$ \\
Slope & -0.328 & 0.106 & -3.794 & $<0.001^{* * *}$ \\
Low intensity & -5.218 & 1.375 & 2.302 & $0.024^{*}$ \\
Moderate intensity & 3.344 & 1.453 & 4.611 & $<0.001^{* * *}$ \\
Clay & 0.140 & 0.030 & 3.12 & $0.002^{* *}$ \\
Interactions & & & 3 & $0.004^{* *}$ \\
TSIS x Macro & 0.44 & 0.14 & -4.68 & $<0.001^{* * *}$ \\
TSIS x Slope & 0.042 & $2.41 \times 10^{-5}$ & 3.738 & $<0.001^{* * *}$ \\
MAP x Clay & $-1.13 \times 10^{-4}$ & 0.183 & -2.279 & $0.025^{*}$ \\
TSIS x Low intensity & 0.685 & 0.193 & &
\end{tabular}

MAP: mean annual precipitation; TSIS: temperature seasonality; slope: terrain slope; exposed: exposed position according to macrotopography; clay: clay content; low and moderate intensity: low and moderate grazing intensity.

$$
y=\sum_{i=1}^{s} \beta_{i} P_{i}+\delta_{A V} \sum_{\substack{i, j=1 \\ i<j}}^{s} P_{i} P_{j}+b X+\varepsilon
$$

where the sum

$$
\sum_{\substack{i, j=1 \\ i<j}}^{s} P_{i} P_{j}
$$

is a measure of the relative abundance of plant guild proportions and is maximum when guilds are all equally represented (Kirwan and others 2009 and 2007). $\delta_{\mathrm{AV}}$ is the single common interaction coefficient.

In contrast, Model 3 (separate pairwise interactions) hypothesizes that effects of pairwise interactions between plant guilds may be different from each other and dependent on the relative abundance of each plant guild:

$$
y=\sum_{i=1}^{s} \beta_{i} P_{i}+\sum_{\substack{i, j=1 \\ i<j}}^{s} \delta_{i j} P_{i} P_{j}+b X+\varepsilon
$$

Thus, the term $\delta_{i j}$ indicates the strength of the interaction between the plant guilds $i$ and $j$, which is modulated by the relative abundance of both groups $\left(P_{i}\right.$ and $\left.P_{j}\right)$.
Model 4 adds the possibility of including pairwise interactions between plant guild proportions and abiotic environmental variables:

$$
y=\sum_{i=1}^{s} \beta_{i} P_{i}+\sum_{\substack{i, j=1 \\ i<j}}^{s} \delta_{i j} P_{i} P_{j}+b X+\sum_{i=1}^{s} \beta_{i} P_{i} X+\varepsilon
$$

We selected $P_{i} X$ candidate terms with a semiautomatic approach, following Rodríguez and others (2020). We used the glmulti function from the glmulti package (Calcagno 2015) with the genetic algorithm option. We included the explanatory variables of Model 0 (TSIS, MAP, macrotopography, slope, clay content and grazing intensity) and the three most abundant plant guilds (grass, forb and legume) as explanatory variables, and the residuals of the geophysical model from Rodríguez and others (2020) as a response variable (i.e., Model 0 with intercept, since glmulti function requires it). This semiautomatic process began by obtaining a best subset of models using the corrected Akaike information criterion (AICc), appropriate when $\mathrm{n} / \mathrm{k}$ is less than $40, \mathrm{n}$ being the sample size and $\mathrm{k}$ the number of parameters in the most complex model (Symonds and Moussalli 2011). We selected the best model and its equivalents obtained by the genetic algorithm, which were those within two Akaike information criterion-corrected ( $\triangle$ AICc) values of the best model, as a $\Delta$ AICc $<2$ indicates that the candidate model is almost as good as the best model (Burnham and Anderson 2002). 
For this set of models, we built averaged models using the MUMIn package (Barton 2015). We calculated partial standardized coefficients, obtained by multiplying the unstandardized coefficient in the model by the partial standard deviation of the variable, which is a function of the standard deviation of the variable, the sample size, the number of variables in the model and the variance inflation factor of the variable (Barton 2015). We selected all the variables with significant effects (alone or in interaction with each other) in the conditional average model, which was preferred over the full average model because we wanted to avoid excessive shrinkage effects at this moment of the modeling procedure (Grueber and others 2011). To finally obtain Model 4, we added these terms to Model 3, and removed those which were not significant according to an F-test by the anova function in $\mathrm{R}$, comparing the model with one lacking the corresponding term (de Vries and others 2012).

Model 5 inserts the hypothesis of a triple interaction effect among the plant guilds:

$$
\begin{aligned}
y= & \sum_{i=1}^{s} \beta_{i} P_{i}+\sum_{\substack{i, j=1 \\
i<j}}^{s} \delta_{i j} P_{i} P_{j}+\mu_{i j k} P_{i} P_{j} P_{k}+b X \\
& +\sum_{i=1}^{s} \beta_{i} P X+\varepsilon
\end{aligned}
$$

$\mu_{i j k}$ being a coefficient modulated by three of the four plant guilds $\left(P_{i} P_{j} P_{k}\right)$.

Finally, Model 6 includes a term $(\theta)$ that represents the shape of the interaction relationship,

$$
\begin{aligned}
y= & \sum_{i=1}^{s} \beta_{i} P_{i}+\sum_{\substack{i, j=1 \\
i<j}}^{s} \delta_{i j}\left(P_{i} P_{j}\right)^{\theta}+\mu_{i j k}\left(P_{i} P_{j} P_{k}\right)^{\theta}+b X \\
& +b_{n} X_{n}+\sum_{i=1}^{s} \beta_{i}(P X)^{\theta}+\varepsilon
\end{aligned}
$$

being a straight line when $\theta=1$. This model was fitted with the nls $R$ function, using the coefficients of Model 5 as starting values (Connolly and others 2013).

Once the models 0-6 were built, we compared them sequentially by F-test using the "anova" $\mathrm{R}$ function and the likelihood ratio test ("Irtest") function in the lmtest $\mathrm{R}$ package (Hothorn and others 2019). These analyses facilitated the test of whether the terms added in a model provided significant information with respect to the previous model. Additionally, we calculated the AIC difference of models $1-5$ with Model 0 ( $\Delta$ AIC) to ac- count for the improvement provided for each model, including plant guilds compared to the null model. Among models 0-6, we selected the best model considering two criteria. First, as models 0-6 are sequentially and hierarchically more complex, the best model should significantly improve its precedent model. Hence, its corresponding F and likelihood ratio tests were required to be significant. Second, the best model could not be considered equivalent to Model 0 . To account for this statement, $\triangle \mathrm{AIC}$ was required to be higher than 2 (Burnham and Anderson 2002).

We used the emmeans package (Lenth and others 2019) to estimate SOC stocks under certain conditions according to the selected model. Firstly, in order to show a complete perspective of the effects of plant guilds, we calculated the predicted effects of the model for all possible combinations of grasses, forbs and legumes, fixing the rest of the variables at their mean value. Sedges were fixed at $0 \%$ because of their low effects on SOC, since they were not involved in any significant interaction (Table 2) and given their low mean proportion $(2 \%)$. We built a ternary plot with the ggtern package (Hamilton and Ferry 2018) to show predicted SOC variation across plant guild proportions. Secondly, to discuss the effects of legumes at different grass and forb proportions, we used the same methodology to plot SOC variation across a legume proportion gradient under: (1) codominance scenario where grasses and forbs accounted for equal proportions (50:50 of the non-legume proportion); (2) a forb-dominance scenario where forb/grass proportions were 80:20 of the non-legume proportion; and (3) a grass-dominance scenario where forb/grass proportion was 20:80 of the non-legume proportion. Thirdly, to study the effect of grasses at different grazing intensities, we drew SOC variation across a grass proportion gradient at the three grazing intensity levels under a forb:legume codominance scenario. We complemented the information provided with the last two plots with the changes in the slope produced along the corresponding legume and grass proportion gradients. We calculated slope at each point as

$$
\text { Slope }=\frac{y_{2}-y_{1}}{x_{2}-x_{1}}
$$

$y_{2}$ and $x_{2}$ being the values corresponding to each integer value of $x$, and $y_{1}$ and $y_{1}$ the values of the point $x_{2}-1$ (Nagle and others 2017). 
Table 2. Model Comparison Results.

\begin{tabular}{|c|c|c|c|c|c|c|c|c|c|}
\hline \multirow[t]{2}{*}{ Model } & \multirow[t]{2}{*}{ Description } & \multirow[t]{2}{*}{ AIC } & \multirow[t]{2}{*}{$\Delta \mathrm{AIC}$} & \multicolumn{3}{|c|}{ Sequential $\mathrm{F}$ test } & \multicolumn{3}{|c|}{$\begin{array}{l}\text { Sequential loglikelihood ratio } \\
\text { test }\end{array}$} \\
\hline & & & & $\begin{array}{l}\text { Sum of } \\
\text { squares }\end{array}$ & $\begin{array}{l}F \\
\text { value }\end{array}$ & $\begin{array}{l}p \\
\text { value }\end{array}$ & $\begin{array}{l}\text { Loglikelihood } \\
\text { ratio }\end{array}$ & $\begin{array}{l}\text { Chi- } \\
\text { square }\end{array}$ & $\begin{array}{l}p \\
\text { value }\end{array}$ \\
\hline Model 0 & Null model & 11.53 & 0.00 & & & & 8.24 & & \\
\hline Model 1 & Single effects model & 14.45 & 2.92 & 0.15 & 1.06 & 0.37 & 9.78 & 3.08 & 0.38 \\
\hline Model 2 & Average pairwise interactions & 16.40 & 4.88 & 0.00 & 0.04 & 0.84 & 9.80 & 0.04 & 0.84 \\
\hline $\begin{array}{l}\text { Model } 3 \\
0.01\end{array}$ & Pairwise interactions & 9.66 & - & 1.87 & 0.73 & 3.11 & 0.01 & 18.17 & 16.75 \\
\hline Model 4 & $\begin{array}{l}\text { Pairwise interactions + interac- } \\
\text { tions with other variables }\end{array}$ & 1.59 & - & 9.94 & 0.45 & 4.82 & 0.01 & 24.21 & 12.07 \\
\hline \multicolumn{10}{|l|}{0.00} \\
\hline Model 5 & $\begin{array}{l}\text { Triple interaction }+ \text { interactions } \\
\text { with other variables }\end{array}$ & - & & 4.03 & - & & 15.56 & 0.26 & 5.87 \\
\hline 0.02 & 28.06 & 7.63 & 0.01 & & & & & & \\
\hline Model 6 & $\begin{array}{l}\text { Triple interaction }+ \text { interactions } \\
\text { with other variables }+ \text { nonlinear } \\
\text { effects of interactions }\end{array}$ & 2.99 & - & 8.54 & - & - & - & 24.50 & 0.60 \\
\hline
\end{tabular}

AIC: Akaike information criterion of each model. $\triangle A I C$ : change in AIC respect to Model O. Sequential tests of each model were performed against the previous model. For Model 6 sequential F-test was not performed since this test is incompatible with nonlinear least square models.

\section{RESULTS}

The best model explaining SOC stocks included the triple interaction between grasses, legumes and forbs, in addition to plant guild proportion and pairwise interactions between grasses, legumes and forbs. Furthermore, the interaction between grass proportion and grazing intensity also entered the best model, with a $\triangle$ AIC of -15.56 (Model 5; Tables 2 and 3). Testing the possibility of nonlinearity of interaction effects of Model 5 (that is, Model 6) did not improve the model (Chi-square $=12.7 ; p$ value $=0.44$; Table 2 ). The effects of sedges were independent of other plant guilds and environmental factors, yielding extremely low SOC stocks (Table 3). Considering these results and the scarcity of sedges in our dataset, we focus on the other three guilds.

SOC stocks were maximized at balanced grass and forb mixtures ( $40 \%$ to $60 \%$ grasses and $20 \%$ to $45 \%$ forbs, approximately) combined with moderate legume proportion (10\% to $30 \%$, approximately), according to Model 5 (Table 3 and Figure 1). Legumes enhanced SOC storage when mixed with either grasses or forbs, but only at low to moderate legume proportions (Figure 2). SOC storage increased with legume proportion, up to 717\% legumes, depending on neighbors (Figure 2). At legume proportions above $7-17 \%$, SOCS decreased with increased legume proportion (Figure 2). This enhancement effect was maximum when grasses and forbs were at an equivalent proportion, whereas it was moderated in the grassdominance scenario and strongly reduced in the forb-dominance scenario.

On the other hand, the positive effects of grass proportion on SOC stocks were strongly conditioned by grazing intensity, modifying the patterns of the SOC-plant guild relationship (Figure 3; Table 3). At moderate grazing intensities (Figure 3B), SOC stocks reached their maximum values at 7 $17 \%$ legume proportions and $40-60 \%$ of grass and forb proportions. In contrast, at high-moderate intensities (Figure 3), SOC increased with grass proportions, reaching maximum values in grasslands with $100 \%$ of grasses. Moreover, the SOC grasses relationship was always positive at this grazing regime (Figure S4). Finally, the SOC pattern at low grazing intensities was intermediate between the previous ones (Figures 3 and S4): SOC stocks were maximized at both intermediate plant guild values and high grass proportions. 
Table 3. Results of the Final Selected Diversity Interaction Model.

\begin{tabular}{|c|c|c|c|c|}
\hline Model term & Estimate & SE & $t$ value & $p$ value \\
\hline \multicolumn{5}{|l|}{ Biodiversity variables } \\
\hline Grasses & 0.078 & 0.031 & 2.53 & $0.014^{*}$ \\
\hline Sedges & 0.077 & 0.032 & 2.41 & $0.019^{*}$ \\
\hline Legumes & 0.0441 & 0.037 & 1.18 & 0.24 \\
\hline Forbs & 0.072 & 0.031 & 2.31 & $0.024^{*}$ \\
\hline Grasses x Sedges & $-7 \times 10^{-5}$ & $2.4 \times 10^{-4}$ & -0.28 & 0.78 \\
\hline Grasses x Legumes & $1.1 \times 10^{-4}$ & $3.4 \times 10^{-4}$ & -0.28 & 0.75 \\
\hline Grasses x Forbs & $-1.3 \times 10^{-4}$ & $7.6 \times 10^{-5}$ & -1.77 & 0.08 \\
\hline Sedges x Legumes & $5 \times 10^{-5}$ & $6.2 \times 10^{-4}$ & 0.9 & 0.932 \\
\hline Sedges $\times$ Forbs & $-1.1 \times 10^{-4}$ & $2.7 \times 10^{-4}$ & -0.39 & 0.696 \\
\hline Legumes $\times$ Forbs & $-8 \times 10^{-5}$ & $4.8 \times 10^{-4}$ & -0.17 & 0.868 \\
\hline Grasses x Forbs x Legumes & $2.3 \times 10^{-5}$ & $9 \times 10^{-6}$ & 2.42 & $0.018^{*}$ \\
\hline \multicolumn{5}{|l|}{ Environmental variables } \\
\hline TSIS & -1.171 & 0.419 & -2.80 & $0.007^{* *}$ \\
\hline Slope & -0.333 & 0.105 & -3.17 & $0.002 * * *$ \\
\hline Macrotopography & -5.144 & 1.977 & -2.60 & $0.011^{*}$ \\
\hline MAP & 0.0031 & 0.001 & 4.26 & $<0.001^{* * *}$ \\
\hline Clay & 0.112 & 0.029 & 3.90 & $<0.001^{* * *}$ \\
\hline Low intensity & -8.258 & 2.626 & -3.15 & $0.002^{* *}$ \\
\hline Medium intensity & 0.168 & 2.743 & 0.06 & 0.951 \\
\hline TSIS x Low intensity & 1.126 & 0.356 & 3.16 & $0.002^{* *}$ \\
\hline TSIS x Moderate intensity & 0.058 & 0.367 & 0.16 & 0.875 \\
\hline TSIS x Macrotopography & 0.677 & 0.263 & 2.58 & $0.012^{*}$ \\
\hline TSIS x Slope & 0.043 & 0.014 & 3.07 & $0.003 * *$ \\
\hline MAP x Clay & $-9 \times 10^{-5}$ & $2.3 \times 10^{-5}$ & -3.07 & $<0.001^{* * *}$ \\
\hline \multicolumn{5}{|c|}{ Biodiversity $x$ environmental variables } \\
\hline Grass x Low intensity & -0.005 & 0.0033 & -1.53 & 0.13 \\
\hline Grass x Moderate intensity & -0.0098 & 0.0027 & -3.64 & $<0.001^{* * *}$ \\
\hline
\end{tabular}

Grasses: proportion of grasses; Sedges: proportion of Sedges; Legumes: proportion of legumes; Forbs: proportion of forbs; MAP: mean annual precipitation; TSIS: temperature seasonality; slope: terrain slope; exposed: exposed position according to macrotopography; clay: clay content; low and moderate intensity: low and moderate grazing intensity.

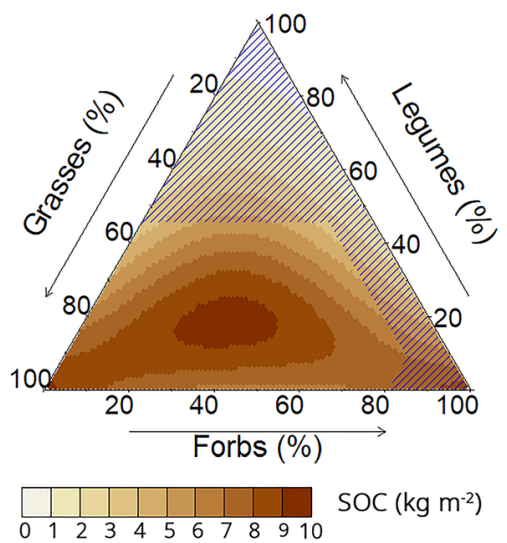

Figure 1. Ternary plot showing predicted SOC values at different guild proportions for the three guilds showing interacting effects on SOC stocks $\left(\mathrm{kg} \mathrm{m}^{-2}\right)$. Striped areas correspond to extrapolated predictions, as those particular guild proportions were not present in the PASTUS database. Sedges were fixed at $0 \%$. Other variables in the model were fixed at their mean value.

\section{Discussion}

Consistency Between Plant Guild Effects on SOC Stocks in Natural Grasslands and Experimental Systems

SOC storage represents a complex equilibrium between primary production (inputs) and organic matter decomposition (outputs) that depends on multiple environmental factors, including climate, soil texture and nutrients, and land management (Jenny 1941; Schlesinger 1977; Jackson and others 2017). Our results demonstrate that some guilds at low proportions can have positive effects on SOC, but also that those enhancement effects can disappear or shift when the proportions among guilds are modified. In our DIM (Table 1 and Figure 1), the critical role of legumes on SOC is not surprising, since their symbiosis with rhizobia bacteria allows them to fix $\mathrm{N}_{2}$ from the atmosphere (McGrath and others 2014), having large effects on $\mathrm{N}$ availability and supply (Zanetti and others 1997; Spehn and 


\section{- Co-dominance $*$ Grass dominance $\star$ Forb dominance}
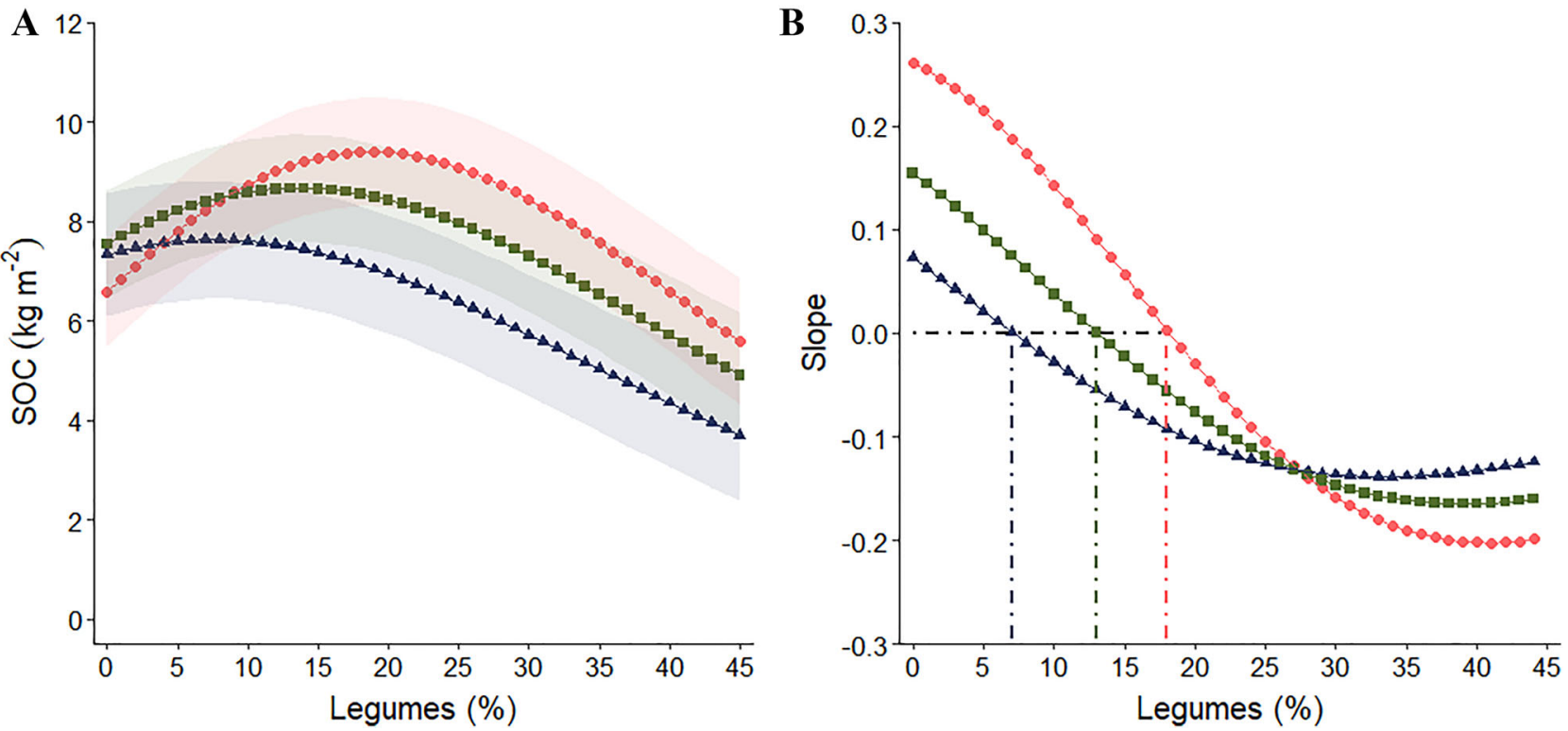

Figure 2. A: Average values of soil organic carbon stocks (SOC, y axis) depending on legume proportion (x axis). Three curves are shown depending on the composition of legumes, grasses and forbs. Considering the remaining fraction once legume proportion is discounted; triangle: forb/grass proportions of 80:20 (forb dominance); square: forb/grass proportions of 20:80 (grass dominance); circle: forb/grass proportions of 50:50 (codominance). Sedges were fixed at 0\%. Other variables in the model were fixed at their mean value. B: Slope of the lines shown in $\mathbf{A}$, dashed lines indicate the percentage of legumes at which slope is 0 .

others 2002; Scherer-Lorenzen and others 2003). These effects on soil $\mathrm{N}$ may alter SOC inputs and outputs among other ecosystem processes (Hector and others 1999; Fornara and Tilman 2008).

However, what is original in our work is the changing role of legumes on SOC storage depending on plant diversity and plant guild interactions. Former studies have reported positive, neutral and negative effects of legumes on SOC (Steinbeiss and others 2008; Lange and others 2015; Wu and others 2017). Results from our DIM are novel because they suggest that those effects could be dependent on legume biomass proportion, as found in the case of Pyrenean natural grasslands. Nyfeler and others $(2009,2011)$ found similar responses of plant $\mathrm{N}$ and yield to legume proportions in an experimental work, which may be behind the soc-legume relationship we found. At low proportions (0$17 \%)$, an increase in legumes noticeably enhanced the positive effect on SOC (Figures 1 and 2), which could be classified as a keystone effect (Mills and Doak 1993). Positive effects of legumes on SOC may have three different non-excluding explanations according to Zhao and others (2014). Firstly, legumes would promote an increase in primary productivity of plant communities through increased $\mathrm{N}$ availability, which would lead to an in- crease in SOC (Wu and others 2017). Secondly, positive effects of legumes on SOC can be attributed to low $\mathrm{C} / \mathrm{N}$ ratios of legume residues (i.e., litter, root exudates...), more similar to soil microorganisms and soil organic matter than other plant residues (Jensen and others 2012). Substrates with low $\mathrm{C} / \mathrm{N}$ ratios can reduce microbial $\mathrm{N}$ acquisition and increase their carbon use efficiency, facilitating humification processes and plant residue decomposition into soil organic matter (Spohn and others 2016). Thirdly, $\mathrm{N}$ inputs through legumes may inhibit the production of oxidative enzymes to degrade the more recalcitrant compounds, leading to reduced ecosystem $\mathrm{CO}_{2}$ emissions and $\mathrm{C}$ losses (De Deyn and others 2011; Spohn and others 2016).

On the other hand, in our study, when legume proportions were high, they had a negative effect on SOC according to our model (Figures 1 and 2). Negative effects of legumes on SOC stocks have been attributed to a decrease in community root biomass (Lange and others 2015). Recent work by Prommer and others (2020) suggests that the allocation of carbon to roots is less necessary at the community level when legumes are present, due to the increase in available $\mathrm{N}$ they fix. Furthermore, Henneron and others (2019) found that the resource acquisitive strategy of legumes, with high 
A

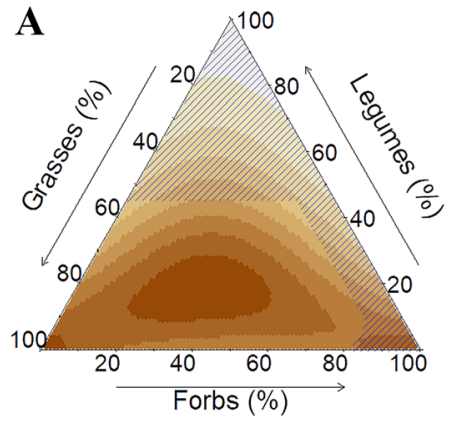

B

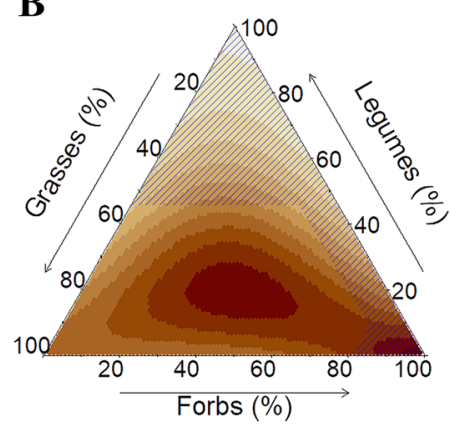

C

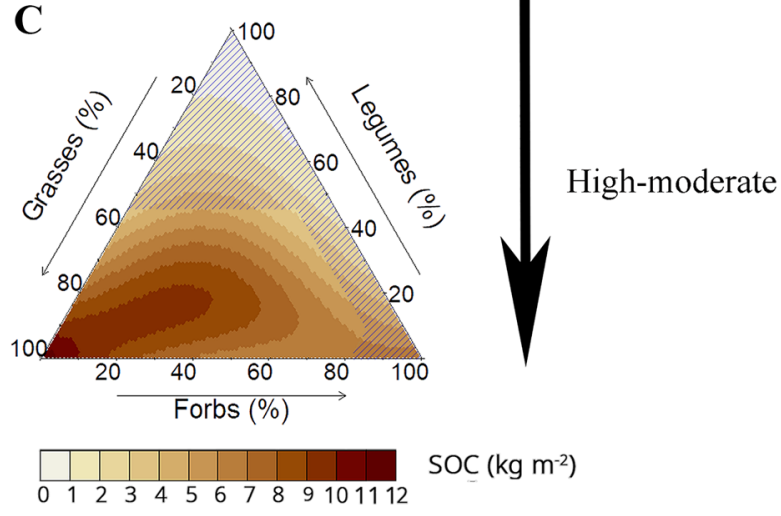

Figure 3. Ternary plots showing predicted SOC values at different guild proportions for the three guilds showing interacting effects on SOC stocks $\left(\mathrm{kg} \mathrm{m}^{-2}\right)$. Striped areas correspond to extrapolated predictions, as those particular guild proportions were not present in the PASTUS database. Sedges were fixed at $0 \%$. Grazing intensity was fixed at A: low intensity; $\mathbf{B}$ moderate intensity and $\mathbf{C}$ high-moderate intensity. Other variables in the model were fixed at their mean value.

photosynthetic activity and capacity and high root metabolic activity, exudation and death, may enhance soil microbial activity, depleting SOC stocks (i.e., rhizosphere priming effect; Kuzyakov, 2002). This explanation is also suggested by the findings in Ibañez and others (2020), where high efficiency of legumes in $\mathrm{C}$ capture does not translate into high legume biomass in the grassland. We also suggest that, at some point, pathways for positive effects of legumes on SOC may be reversed. For instance, due to legumes' strategy of producing a more nutrient-rich and short-lived biomass than other plant guilds (Craine and others 2002), high legume proportions may involve less total biomass in the long term, and very low litter $\mathrm{C} / \mathrm{N}$ ratios could lead to higher mineralization rates and less carbon storage (Orwin and others 2010). Despite the fact that labile plant litter components can be a source of microbial-transformed products, and hence, of soil organic matter (Jensen and others 2012; Cotrufo and others 2013), some studies suggest that high-quality litter may have lower incorporation rates into the most stable soil organic matter than low-quality litter when the plant carbon inputs are high enough (Castellano and others 2015; Sollenberger and others 2019). Indeed, this fits in with findings by Ibañez and others (2020) in grasslands in the Pyrenees, where higher legume proportions are associated with lower yield in spite of high legume photosynthetic efficiency. Moreover, at high legume proportions, the additional $\mathrm{N}$ supply provided by $\mathrm{N}_{2}$ fixation may be inhibited because of the reduction in plant competition for soil $\mathrm{N}$ ( $\mathrm{Ny}$ feler and others 2011); hence, the mechanisms which may enhance SOC stocks at low legume proportions could be inhibited at high legume proportions.

\section{Interactions Between Plant Guilds Shaping SOC Stocks}

Importantly, this enhancement effect on legumes over SOC stocks depended on the relative proportions of grasses and forbs, being maximum in the codominance scenario and minimum in the forb dominance scenario, with the grass-dominance scenario in between (Figure 2). Maximum enhancement effects in the codominance scenario suggest a positive diversity effect on SOC stocks. According to experimental evidence, diversity produces spatial (different root depths) and temporal (different growing seasons) niche partitioning (Van Ruijven and Berendse 2005; Mueller and others 2013), which would allow the maximization of resource use (Blair and others 2014), leading to an increased plant productivity (Mason and others 2020) and microbial activity (Lange and others 2015) that would enhance SOC stocks (Chen and others 2018). Importantly, if legume proportions are close to 0 , the variation in SOC stocks due to changes in grass and forb proportions is highly diminished (Figure 1). Hence, besides the keystone effect of legumes, our model suggests a niche complementarity effect (Diaz and Cabido 2001) represented by the triple interaction term (Table 3 ). 
The fact that grasses have slightly better performance on SOC stocks than non-legume forbs could be related to positive synergistic effects between grasses and legumes concerning $\mathrm{N}$ fixation and yield (Kirwan and others 2007; Nyfeler and others 2011; Rasmussen and others 2012; Schipanski and Drinkwater 2012; Ribas and others 2015; Suter and others 2015). Pirhofer-Walzl and others (2012) suggested that grasses could be especially good receivers of legume-derived $\mathrm{N}$ due to their fibrous root systems, which provide grasses with larger root surface and superficiality. Additionally, $\mathrm{N}_{2}$ fixation activity of legumes could be promoted by an increased demand for soil $\mathrm{N}$ on the whole ecosystem, as a consequence of an enhancement of grass root systems driven by the supply of atmospheric $\mathrm{N}_{2}$ fixed by legumes and transferred by litter, dead roots and exudates (Nyfeler and others 2011). That enhancement of grass root systems would also allow grasses to acquire more $\mathrm{N}$ from non-symbiotic sources (Nyfeler and others 2011; Suter and others 2015).

\section{Interaction Effects of Grasses and Management Intensity on SOC Stocks}

In addition to the interaction effects with legumes and forbs, grasses were the only plant guild which interacted with an environmental factor to shape SOC stocks. Interactions between vegetation and other variables affecting SOC stocks have been anticipated (Chang and others 2018; Chen and others 2018; Yuan and Jiang 2021). However, a recent study in the Northern Iberian Peninsula reported that only soil microbial nitrogen was affected by interactions between plant guilds and environmental factors, among a series of soil activity and fertility parameters involved in the $\mathrm{C}$ and N cycles (Debouk and others 2020). The effects of grass proportions on SOC stocks varied depending on grazing intensity level (Figure 2), a factor known to affect SOC through different paths, such as regulating the quantity and quality of organic matter returned to soil (Bardgett and Wardle 2003) or affecting soil respiration and nutrients by animal trampling or soil microbiota alteration ( $\mathrm{Lu}$ and others 2017). However, positive effects of grazing on SOC stocks are often related to the promotion of aboveground and root biomass production (Franzluebbers and others 2000; Zeng and others 2015), and therefore this interaction effect could be related to the higher regrowth rates and productivity of grasses under moderate grazing pressures, when compared to the other groups (Sebastià and Puig
2008; Ganjurjav and others 2019). Our model suggests that only under relatively high grazing intensities (in our natural grasslands all grazing intensities are actually low; see methods) can grass dominance $(<60 \%)$ overcome the SOC decrease caused by the loss of the equilibrium between grass, forb and legume proportions (Figure 1).

\section{Implication of Results in the Current Ecological Framework}

Most of the previous studies addressing plant guild effects on SOC of grasslands were carried out at local scales and/or employing experimental assemblages (Fornara and Tilman 2008; Prommer and others 2020), not natural ecosystems as considered here. Moreover, most of these studies only considered the effect of plant guild richness and the presence or absence of the different plant guilds on SOC (Lange and others 2015; Wu and others 2017), although guild proportion effects have been described for other ecosystem functions, including yield (Kirwan and others 2007; Finn and others 2013; Ribas and others 2015). In contrast, what our model suggests is that: plant guild effects vary depending on their mass proportion in plant communities; some guilds, even in small proportions, can greatly enhance ecosystem function; those effects can be reversed at increasing proportions; and those observed effects stand over a wide range of grasslands and environmental conditions at regional scale. Hence, in addition to direct effects, shifts in plant guilds will have clear consequences on the rest of the biota (i.e., other plants, microbes), triggering a set of cascading effects in the ecosystem (Loranger-Merciris and others 2006; Cornwell and others 2008; De Deyn and others 2008). We postulate that legume proportion determines the predominance of some processes over others, leading to SOC accumulation at moderate legume proportions and to SOC depletion at high legume proportions.

Our results are also relevant for functional ecology, since they illustrate the power and usefulness of plant guilds to study keystone effects and interactions in ecosystems. In the last few decades, PFTs or plant guild approaches have been described as inferior methods in comparison with continuous trait indexes (Mason and others 2005; Funk and others 2017). However, these last methods focus on testing concrete hypotheses, like the mass ratio (Grime 1998; Díaz and others 2007) or niche complementarity (Villéger and others 2008; de Bello and others 2016) hypotheses. In the present study, we detected other critical functional effects 
of plant guilds on SOC storage, like keystone legume effects (Spehn and others 2002) or guild interaction effects (Fry and others 2014). Additionally, our work demonstrated that plant guilds are also valid to detect niche complementarity or diversity effects (Diaz and Cabido 2001), because intermediate legume, grass and forb proportions enhanced SOC stocks, as well as mass ratio or dominance effects (Grime 1998; Díaz and others 2007), since SOC stocks reached maximum values under grass dominance at relatively high grazing intensities. Thus, our results suggest that particular environmental conditions could modify guild (biodiversity) interaction effects on ecosystem functions, and also that several of the current theoretical ecological hypotheses could coexist to explain the observed soil organic carbon distribution patterns.

\section{Conclusion}

Our DIM revealed that SOC storage in the Pyrenees not only depends on regional, landscape and local scale factors, including climate and topography, but also on the contribution of the different plant functional guilds and interactions between the guilds. Additionally grass proportion effects were modulated by grazing intensity. In particular, legumes had a complex effect as they enhanced SOC stocks at low proportions and reduced them at high proportions. The magnitude of these effects depended on the relative composition of other guilds in the grassland, being maximum when grass and forb proportions, besides legumes, were codominant. Different effects of the ability of legumes to fix atmospheric $\mathrm{N}$ and their high nutrient acquisition strategy were probably behind this pattern. Our results stress the importance of the keystone role of the $\mathrm{N}_{2}$ fixation rate of legumes on SOC stocks in natural grasslands and provide a strong argument for species diversity conservation efforts under climate change conditions. In addition, our findings can facilitate the elaboration of regional and local strategies to ameliorate the soil capacity to absorb carbon, contributing to the global effort to preserve terrestrial carbon pools.

\section{ACKNOWLEDGEMENTS}

We would like to express our thanks to the many people who collaborated in fieldwork, sample processing and data analysis over time. Research in this paper is based on the PASTUS database, compiled from different funding sources over time, the most relevant being: the EU Interreg III- A Pro- gramme (I3A- 4- 147- E) and the POCTEFA Programme/Interreg IV- A (FLUXPYR, EFA 34/08); the Spanish Science Foundation FECYT- MICINN (CARBOPAS: REN2002- 04300- C02- 01; CARBOAGROPAS: CGL2006- 13555- C03- 03 and CAPAS: CGL2010- 22378- C03-01); the Foundation Catalunya- La Pedrera; and the Spanish Institute of Agronomical Research INIA (CARBOCLUS: SUM2006- 00029- C02- 0). This work was funded by the Spanish Science Foundation FECYTMINECO (BIOGEI: GL2013- 49142- C2- 1- R and IMAGINE: CGL2017-85490-R) and the University of Lleida (PhD Fellowship to AR). This research article has received a grant for its linguistic revision from the Language Institute of the University of Lleida (2021 call).

\section{FUNDING}

Open Access funding provided thanks to the CRUECSIC agreement with Springer Nature.

\section{OPEN ACCESS}

This article is licensed under a Creative Commons Attribution 4.0 International License, which permits use, sharing, adaptation, distribution and reproduction in any medium or format, as long as you give appropriate credit to the original author(s) and the source, provide a link to the Creative Commons licence, and indicate if changes were made. The images or other third party material in this article are included in the article's Creative Commons licence, unless indicated otherwise in a credit line to the material. If material is not included in the article's Creative Commons licence and your intended use is not permitted by statutory regulation or exceeds the permitted use, you will need to obtain permission directly from the copyright holder. To view a copy of this licence, visit $h$ ttp://creativecommons.org/licenses/by/4.0/.

\section{REFERENCES}

Bardgett RD, Wardle DA. 2003. Herbibore-mediated Linkages Between Abobeground and Belowground Communities. Ecology 84:2258-2268.

Barton K. 2015. MuMIn: Multi-model inference. R package version 1.9.13. Version 1:18. https://cran.r-project.org/web/ packages/MuMIn/. Last accessed 02/05/2019

Batjes NH. 1996. Total carbon and nitrogen in the soils of the world. Eur J Soil Sci 65:10-21. https://doi.org/10.1111/j.136 5-2389.1996.tb01386.x. Last accessed 05/09/2019 
Blair J, Nippert J, Briggs J. 2014. Grassland ecology. In: Monson R, editor. Ecology and the Environment. The Plant Sciences, vol 8. Springer New York. pp 389-423. https://doi.org/10.10 07/978-1-4614-7501-9_14. Last accessed 13/02/2021

Blondel J. 2003. Guilds or functional groups: Does it matter? Oikos 100:223-31. https://doi.org/10.1034/j.1600-0706.2003. 12152.x. Last accessed 22/07/2019

Bouyoucos GJ. 1936. Directions for making mechanical analysis of soils by the hydrometer method. Soil Sci 42:225-2230.

Burnham KP, Anderson DR. 2002. Model Selection and Multimodel Inference: A Practical Information-Theoretic Approach (2nd ed). Springer New York. http://linkinghub.elsevier.com/ retrieve/pii/S0304380003004526

Calcagno V. 2015. Package glmulti 1.0.7, Model selection and multimodel inference made easy. Community Ecol Packag:120. https://cran.rproject.org/web/packages/glmulti/index.htm 1. Last accessed 02/05/2019

Canadell JG, Le Quéré C, Raupach MR, Field CB, Buitenhuis ET, Ciais P, Conway TJ, Gillett NP, Houghton RA, Marland G. 2007. Contributions to accelerating atmospheric CO2 growth from economic activity, carbon intensity, and efficiency of natural sinks. Proc Natl Acad Sci U S A 104:18866-70. http:// www.ncbi.nlm.nih.gov/pubmed/17962418. Last accessed 06/ 08/2019

Canals RM, Sebastià MT. 2000. Analyzing mechanisms regulating diversity in rangelands through comparative studies: A case in the southwestern Pyrennees. Biodivers Conserv 9:965984.

Carol Adair E, Hooper DU, Paquette A, Hungate BA. 2018. Ecosystem context illuminates conflicting roles of plant diversity in carbon storage. Ecol Lett 21:1604-19. http://ww w.ncbi.nlm.nih.gov/pubmed/30152093. Last accessed 05/09/ 2019

Carreras J, Diego FC. 2006. Cartografia dels hàbitats de Catalunya 1:50000. (Generalitat de Catalunya, editor.). Barcelona

Castellano MJ, Mueller KE, Olk DC, Sawyer JE, Six J. 2015. Integrating plant litter quality, soil organic matter stabilization, and the carbon saturation concept. Glob Chang Biol 21:3200-9. https://doi.org/10.1111/gcb.12982. Last accessed $14 / 05 / 2021$

Chang Q, Wang L, Ding S, Xu T, Li Z, Song X, Zhao X, Wang D, Pan D. 2018. Grazer effects on soil carbon storage vary by herbivore assemblage in a semi-arid grassland. Mukul S, editor. J Appl Ecol 55:2517-26. https://doi.org/10.1111/1365-2 664.13166. Last accessed 04/02/2019

Chen S, Wang W, Xu W, Wang Y, Wan H, Chen D, Tang Z, Tang $X$, Zhou G, Xie Z, Zhou D, Shangguan Z, Huang J, He JS, Wang Y, Sheng J, Tang L, Li X, Dong M, Wu Y, Wang Q, Wang Z, Wu J, Stuart Chapin F, Bai Y. 2018. Plant diversity enhances productivity and soil carbon storage. Proc Natl Acad Sci U S A 115:4027-32. https://doi.org/10.1073/pnas.170029811 4. Last accessed 05/09/2019

Connolly J, Bell T, Bolger T, Brophy C, Carnus T, Finn JA, Kirwan L, Isbell F, Levine J, Lüscher A, Picasso V, Roscher C, Sebastia MT, Suter M, Weigelt A. 2013. An improved model to predict the effects of changing biodiversity levels on ecosystem function. J Ecol 101:344-355.

Connolly J, Sebastià MT, Kirwan L, Finn JA, Llurba R, Suter M, Collins RP, Porqueddu C, Helgadóttir Á, Baadshaug OH, Bélanger G, Black A, Brophy C, Čop J, Dalmannsdóttir S, Delgado I, Elgersma A, Fothergill $M$, Frankow-Lindberg BE, Ghesquiere A, Golinski P, Grieu P, Gustavsson AM, Höglind M, Huguenin-Elie O, Jørgensen M, Kadziuliene Z, Lunnan T,
Nykanen-Kurki P, Ribas A, Taube F, Thumm U, De Vliegher A, Lüscher A. 2018. Weed suppression greatly increased by plant diversity in intensively managed grasslands: A continental-scale experiment. Inderjit, editor. J Appl Ecol 55:85262. https://doi.org/10.1111/1365-2664.12991. Last accessed $20 / 02 / 2020$

Cornwell WK, Cornelissen JHC, Amatangelo K, Dorrepaal E, Eviner VT, Godoy O, Hobbie SE, Hoorens B, Kurokawa H, Pérez-Harguindeguy N, Quested HM, Santiago LS, Wardle DA, Wright IJ, Aerts R, Allison SD, Van Bodegom P, Brovkin V, Chatain A, Callaghan TV, Díaz S, Garnier E, Gurvich DE, Kazakou E, Klein JA, Read J, Reich PB, Soudzilovskaia NA, Vaieretti MV, Westoby M. 2008. Plant species traits are the predominant control on litter decomposition rates within biomes worldwide. Ecol Lett 1 1:1065-1071.

Cotrufo MF, Wallenstein MD, Boot CM, Denef K, Paul E. 2013. The Microbial Efficiency-Matrix Stabilization (MEMS) framework integrates plant litter decomposition with soil organic matter stabilization: Do labile plant inputs form stable soil organic matter? Glob Chang Biol 19:988-95. http s://doi.org/10.1111/gcb.12113

Craine JM, Tilman D, Wedin D, Reich P, Tjoelker M, Knops J. 2002. Functional traits, productivity and effects on nitrogen cycling of 33 grassland species. Funct Ecol 16:563-574.

de Bello F, Carmona CP, Lepš J, Szava-Kovats R, Pärtel M. 2016. Functional diversity through the mean trait dissimilarity: resolving shortcomings with existing paradigms and algorithms. Oecologia 180:933-40. https://doi.org/10.1007/s0044 2-016-3546-0. Last accessed 30/05/2019

Debouk H, Emeterio LS, Marí T, Canals RM, Sebastià MT. 2020 Plant functional diversity, climate and grazer type regulate soil activity in natural grasslands. Agronomy 10:1291. https://ww w.mdpi.com/2073-4395/10/9/1291. Last accessed 03/09/2020

Dengler J, Janišová M, Török P, Wellstein C. 2014. Biodiversity of Palaearctic grasslands: A synthesis. Agric Ecosyst Environ 182:1-14. https://linkinghub.elsevier.com/retrieve/pii/S0167 880913004374. Last accessed 02/03/2019

De Deyn GB, Cornelissen JHC, Bardgett RD. 2008. Plant functional traits and soil carbon sequestration in contrasting biomes. Ecol Lett 11:516-31. http://www.ncbi.nlm.nih.gov/ pubmed/18279352. Last accessed 31/08/2019

De Deyn GB, Shiel RS, Ostle NJ, Mcnamara NP, Oakley S, Young I, Freeman C, Fenner N, Quirk H, Bardgett RD. 2011. Additional carbon sequestration benefits of grassland diversity restoration. J Appl Ecol 48:600-608.

de Lamo X, Sebastià MT. 2006. Role of biogeographical , ecological and management factors on plant diversity in grasslands. In: Lloveras J, González-Rodríguez A, Vázquez-Yañez O, Piñeiro J, Santamaría O, Olea L, Poblaciones MJ, editors. Sociedad Española para el Estudio de los Pastos (SEEP). Vol. 11. Madrid, Spain: Sociedad Española para el Estudio de los Pastos (SEEP). pp 832-834.

de Vries FT, Manning P, Tallowin JRB, Mortimer SR, Pilgrim ES, Harrison KA, Hobbs PJ, Quirk H, Shipley B, Cornelissen JHC, Kattge J, Bardgett RD. 2012. Abiotic drivers and plant traits explain landscape-scale patterns in soil microbial communities. Ecol Lett 15:1230-1239.

Diaz S, Lavorel S, De Bello F, Quétier F, Grigulis K, Robson TM. 2007. Incorporating plant functional diversity effects in ecosystem service assessments. Proc Natl Acad Sci U S A 104:20684-9. Last accessed 13/08/2020

Diaz S, Cabido M. 2001. Vive la différence: plant functional diversity matters to ecosystem processes. Trends Ecol Evol 
16:646-55. https://www.sciencedirect.com/science/article/pi i/S0169534701022832. Last accessed 13/06/2019

Fick SE, Hijmans RJ. 2017. WorldClim 2: new 1-km spatial resolution climate surfaces for global land areas. Int J Climatol 37:4302-15. https://doi.org/10.1002/joc.5086/full. Last accessed 29/03/2018

Finn JA, Kirwan L, Connolly J, Sebastià MT, Helgadottir A, Baadshaug OH, Bélanger G, Black A, Brophy C, Collins RP, Čop J, Dalmannsdóttir S, Delgado I, Elgersma A, Fothergill M, Frankow-Lindberg BE, Ghesquiere A, Golinska B, Golinski P, Grieu P, Gustavsson AM, Höglind M, Huguenin-Elie O, Jørgensen M, Kadziuliene Z, Kurki P, Llurba R, Lunnan T, Porqueddu C, Suter M, Thumm U, Lüscher A. 2013. Ecosystem function enhanced by combining four functional types of plant species in intensively managed grassland mixtures: A 3year continental-scale field experiment. J Appl Ecol 50:365375.

Fornara DA, Tilman D. 2008. Plant functional composition influences rates of soil carbon and nitrogen accumulation. J Ecol 96:314-22. https://doi.org/10.1111/j.1365-2745.2007.01 345.x. Last accessed 20/08/2019

Franzluebbers AJ, Stuedemann JA, Schomberg HH, Wilkinson SR. 2000. Soil organic C and N pools under long-term pasture management in the Southern Piedmont USA. Soil Biol Biochem 32:469-478.

Fry EL, Power SA, Manning P. 2014. Trait-based classification and manipulation of plant functional groups for biodiversityecosystem function experiments. Prinzing A, editor. J Veg Sci 25:248-61. https://doi.org/10.1111/jvs.12068. Last accessed $19 / 08 / 2019$

Funk JL, Larson JE, Ames GM, Butterfield BJ, Cavender-Bares J, Firn J, Laughlin DC, Sutton-Grier AE, Williams L, Wright J. 2017. Revisiting the Holy Grail: Using plant functional traits to understand ecological processes. Biol Rev 92:1156-1173.

Ganjurjav H, Zhang Y, Gornish ES, Hu G, Li Y, Wan Y, Gao Q. 2019. Differential resistance and resilience of functional groups to livestock grazing maintain ecosystem stability in an alpine steppe on the Qinghai-Tibetan Plateau. J Environ Manage. https://doi.org/10.1016/j.jenvman.2019.109579.Las taccessed 21/02/2020.

Garcia-Pausas J, Casals P, Camarero L, Huguet C, Sebastià MT, Thompson R, Romanyà J. 2007. Soil organic carbon storage in mountain grasslands of the Pyrenees: Effects of climate and topography. Biogeochemistry 82:279-289.

Gobierno de Navarra. 2003. Mapa de usos del suelo de Navarra 1:25000. Pamplona, Spain: Gobierno de Navarra

Gómez D. 2008. Pastos de Pirineo: Breve Descripción Ecológica Y Florística. In: Fillat F, García-González R, Gómez D, Reiné R, editors. Pastos del Pirineo. Madrid, Spain. pp 111-39.

Grime JP. 1998. Benefits of plant diversity to ecosystems: Immediate, filter and founder effects. J Ecol 86:902-10. http s://doi.org/10.1046/j.1365-2745.1998.00306.x. Last accessed $13 / 06 / 2019$

Grueber CE, Nakagawa S, Laws RJ, Jamieson IG. 2011. Multimodel inference in ecology and evolution: Challenges and solutions. J Evol Biol 24:699-711.

Hamilton NE, Ferry M. 2018. ggtern: Ternary Diagrams Using ggplot2. J Stat Softw 87:1-17. http://www.jstatsoft.org/v87/c 03/. Last accessed 16/07/2019

Hector A, Bagchi R. 2007. Biodiversity and ecosystem multifunctionality. Nature 448:188-190.
Hector A, Schmid B, Beierkuhnlein C, Caldeira MC, Diemer M, Dimitrakopoulos PG, Finn JA, Freitas H, Giller PS, Good J, Harris R, Högberg P, Huss-Danell K, Joshi J, Jumpponen A, Körner C, Leadley PW, Loreau M, Minns A, Mulder CPH, O'Donovan G, Otway SJ, Pereira JS, Prinz A, Read DJ, Scherer-Lorenzen $M$, Schulze ED, Siamantziouras A-SSD, Spehn EM, Terry AC, Troumbis AY, Woodward FI, Yachi S, Lawton JH. 1999. Plant diversity and productivity experiments in European grasslands. Science (80- ) 286:1123-7. h ttp://www.ncbi.nlm.nih.gov/pubmed/10550043. Last accessed 30/08/2019

Henneron L, Cros C, Picon-Cochard C, Rahimian V, Fontaine S. 2019. Plant economic strategies of grassland species control soil carbon dynamics through rhizodeposition. J Ecol:1-18.

Herz K, Dietz S, Haider S, Jandt U, Scheel D, Bruelheide H. 2017. Drivers of intraspecific trait variation of grass and forb species in German meadows and pastures. Bartha S, editor. J Veg Sci 28:705-16. https://doi.org/10.1111/jvs.12534. Last accessed $27 / 02 / 2021$

Hollingsworth TN, Schuur EAG, Chapin FS, Walker MD. 2008. Plant community composition as a predictor of regional soil carbon storage in Alaskan boreal black spruce ecosystems. Ecosystems 11:629-42. https://doi.org/10.1007/s10021-008-9 147-y. Last accessed 05/09/2019

Hooper DU, Chapin FS, Ewel JJ, Hector A, Inchausti P, Lavorel S, Lawton JH, Lodge DM, Loreau M, Naeem S, Schmid B, Setälä H, Symstad AJ, Vandermeer J, Wardle DA. 2005. Effects of biodiversity on ecosystem functioning: A consensus of current knowledge. Ecol Monogr 75:3-35.

Hothorn T, Zeileis A, Farebrother RW, Cummins C, Millo G, Mitchell D. 2019. Package 'Imtest' (Version 0.9-37). https:// orcid.org/0000-0003-0918-3766. Last accessed 16/07/2019

Ibanez M, Altimir N, Ribas A, Eugster W, Sebastia MT. 2020. Phenology and plant functional type dominance drive CO 2 exchange in seminatural grasslands in the Pyrenees. J Agric Sci 158:3-14.

Jackson RB, Lajtha K, Crow SE, Hugelius G, Kramer MG, Piñeiro G. 2017. The Ecology of Soil Carbon: Pools, Vulnerabilities, and Biotic and Abiotic Controls. Annu Rev Ecol Evol Syst 48:annurev-ecolsys-112414-054234. https://doi.org/10.1146/ annurev-ecolsys-112414-054234

Jenny H. 1941. Factors of soil formation: A System of Quantitative Pedology. New York, USA: Dover Publications.

Jensen ES, Peoples MB, Boddey RM, Gresshoff PM, HauggaardNielsen H, J.R. Alves B, Morrison MJ. 2012. Legumes for mitigation of climate change and the provision of feedstock for biofuels and biorefineries. A review. Agron Sustain Dev 32:329-64. https://doi.org/10.1007/s13593-011-0056-7. Last accessed 22/08/2019

Kirwan L, Connolly RM, Finn JA, Brophy C, Lüscher A, Nyfeler D. 2009. Diversity-Interaction Modeling: Estimating Contributions of Species Identities and Interactions to Ecosystem Function Sebastià Reviewed work (s): Published by: Ecological Society of America content in a trusted digital archive. We Use Information Tec. Ecology 90:2032-2038.

Kirwan L, Lüscher A, Sebastià MT, Finn JA, Collins RP, Porqueddu C, Helgadottir A, Baadshaug OH, Brophy C, Coran C, Dalmannsdóttir S, Delgado I, Elgersma A, Fothergill $M$, Frankow-Lindberg BE, Golinski P, Grieu P, Gustavsson AM, Höglind M, Huguenin-Elie O, Iliadis C, Jørgensen M, Kadziuliene Z, Karyotis T, Lunnan T, Malengier M, Maltoni S, Meyer V, Nyfeler D, Nykanen-Kurki P, Parente J, Smit HJ, Thumm U, Connolly J. 2007. Evenness drives consistent 
diversity effects in intensive grassland systems across 28 European sites. J Ecol 95:530-539.

Kuzyakov Y. 2002. Review: Factors affecting rhizosphere priming effects. J Plant Nutr Soil Sci 165:382-396.

Lange M, Eisenhauer N, Sierra CA, Bessler H, Engels C, Griffiths RI, Mellado-Vázquez PG, Malik AA, Roy J, Scheu S, Steinbeiss S, Thomson BC, Trumbore SE, Gleixner G. 2015. Plant diversity increases soil microbial activity and soil carbon storage. Nat Commun 6.

Lange $M$, Habekost $M$, Eisenhauer N, Roscher C, Bessler $H$, Engels C, Oelmann Y, Scheu S, Wilcke W, Schulze ED, Gleixner G. 2014. Biotic and abiotic properties mediating plant diversity effects on soil microbial communities in an experimental grassland. PLoS One 9.

Legendre P, Legendre L. 1998. Numerical Ecology. 2nd ed. (Elsevier, editor.). Amsterdam

Lenth R, Singmann H, Love J, Buerkne P, Herve M. 2019. Package 'emmeans'. https://cran.r-project.org/web/packages/ emmeans/. Last accessed 18/03/2019

Lipowsky A, Roscher C, Schumacher J, Michalski SG, Gubsch M, Buchmann N, Schulze ED, Schmid B. 2015. Plasticity of functional traits of forb species in response to biodiversity. Perspect Plant Ecol Evol Syst 17:66-77.

Loranger-Merciris G, Barthes L, Gastine A, Leadley P. 2006. Rapid effects of plant species diversity and identity on soil microbial communities in experimental grassland ecosystems. Soil Biol Biochem 38:2336-43. https://www.sciencedirect.co $\mathrm{m} /$ science/article/abs/pii/S0038071706001374. Last accessed $31 / 08 / 2019$

Lu X, Kelsey KC, Yan Y, Sun J, Wang X, Cheng G, Neff JC. 2017. Effects of grazing on ecosystem structure and function of alpine grasslands in Qinghai-Tibetan Plateau: a synthesis. Ecosphere 8:e01656. https://doi.org/10.1002/ecs2.1656. Last accessed 07/08/2019

Manning P, de Vries FT, Tallowin JRB, Smith R, Mortimer SR, Pilgrim ES, Harrison KA, Wright DG, Quirk H, Benson J, Shipley B, Cornelissen JHC, Kattge J, Bönisch G, Wirth C, Bardgett RD. 2015. Simple measures of climate, soil properties and plant traits predict national-scale grassland soil carbon stocks. J Appl Ecol 52:1188-1196.

Mason NWH, Mouillot D, Lee WG, Wilson JB. 2005. Functional richness, functional evenness and functional divergence: The primary components of functional diversity. Oikos 111:112-8. https://doi.org/10.1111/j.0030-1299.2005.13886.x. Last accessed 01/05/2019

Mason NWH, Orwin KH, Lambie S, Waugh D, Pronger J, Carmona CP, Mudge P. 2020. Resource-use efficiency drives overyielding via enhanced complementarity. Oecologia 193:995-1010. https://doi.org/10.1007/s00442-020-04732-7. Lastaccessed 13/02/2021.

McGrath JM, Spargo J, Penn CJ. 2014. Soil Fertility and Plant Nutrition. Encyclopedia of Agriculture and Food Systems, . Elsevier: San Diego. pp 166-184.

Mills LS, Doak DF. 1993. The Keystone-Species Concept in Ecology and Conservation. Bioscience 43:219-24. https://w ww.researchgate.net/publication/255981454. Last accessed $09 / 09 / 2019$

Mou XM, Li XG, Zhao N, Yu YW, Kuzyakov Y. 2018. Tibetan sedges sequester more carbon belowground than grasses: a 13C labeling study. Plant Soil 426:287-298.

Mueller KE, Tilman D, Fornara DA, Hobbie SE. 2013. Root depth distribution and the diversity-productivity relationship in a long-term grassland experiment. Ecology 94:787-93. https://d oi.org/10.1890/12-1399.1. Last accessed 20/02/2020

Nagle C, Casey S, Moore-Russo D. 2017. Slope and Line of Best Fit: A Transfer of Knowledge Case Study. Sch Sci Math 117:13-26. https://doi.org/10.1111/ssm.12203. Last accessed $27 / 01 / 2021$

Nyfeler D, Huguenin-Elie O, Suter M, Frossard E, Connolly J, Lüscher A. 2009. Strong mixture effects among four species in fertilized agricultural grassland led to persistent and consistent transgressive overyielding. J Appl Ecol 46:683-691. https://d oi.org/10.1111/j.1365-2664.2009.01653.x

Nyfeler D, Huguenin-Elie O, Suter M, Frossard E, Lüscher A. 2011. Grass-legume mixtures can yield more nitrogen than legume pure stands due to mutual stimulation of nitrogen uptake from symbiotic and non-symbiotic sources. Agric Ecosyst Environ 140:155-163.

Onipchenko VG, Makarov MI, Akhmetzhanova AA, Soudzilovskaia NA, Aibazova FU, Elkanova MK, Stogova AV, Cornelissen JHC. 2012. Alpine plant functional group responses to fertiliser addition depend on abiotic regime and community composition. Plant Soil 357:103-115.

Orwin KH, Buckland SM, Johnson D, Turner BL, Smart S, Oakley S, Bardgett RD. 2010. Linkages of plant traits to soil properties and the functioning of temperate grassland. J Ecol 98:1074-83. https://doi.org/10.1111/j.1365-2745.2010.01679 .x. Last accessed 06/03/2019

Penin D. 1997. Cartographie des habitats naturels (typologie Corine Biotope) du massif Madres-Coronat, 1st edn. Paris, France: AGRNN/CPIE du Conflent.

Pirhofer-Walzl K, Rasmussen J, Høgh-Jensen H, Eriksen J, Søegaard K, Rasmussen J. 2012. Nitrogen transfer from forage legumes to nine neighbouring plants in a multi-species grassland. Plant Soil 350:71-84. https://doi.org/10.1007/s111 04-011-0882-z. Last accessed 27/08/2019

Poeplau C, Don A. 2013. Sensitivity of soil organic carbon stocks and fractions to different land-use changes across Europe. Geoderma 192:189-201. https://doi.org/10.1016/j.geoderma. 2012.08.003.Lastaccessed09/06/2020.

Prommer J, Walker TWN, Wanek W, Braun J, Zezula D, Hu Y, Hofhansl F, Richter A. 2020. Increased microbial growth, biomass, and turnover drive soil organic carbon accumulation at higher plant diversity. Glob Chang Biol 26:669-81. https://d oi.org/10.1111/gcb.14777. Last accessed 22/08/2019

Rasmussen J, Søegaard K, Pirhofer-Walzl K, Eriksen J. 2012. N2fixation and residual $\mathrm{N}$ effect of four legume species and four companion grass species. Eur J Agron 36:66-74. https://www. sciencedirect.com/science/article/abs/pii/S11610301110010 06. Last accessed 31/08/2019

Ribas A, Llurba R, Gouriveau F, Altimir N, Connolly J, Sebastià MT. 2015. Plant identity and evenness affect yield and trace gas exchanges in forage mixtures. Plant Soil 391:93-108.

Rillig MC, Ryo M, Lehmann A, Aguilar-Trigueros CA, Buchert S, Wulf A, Iwasaki A, Roy J, Yang G. 2019. The role of multiple global change factors in driving soil functions and microbial biodiversity. Science (80- ) 366:886-90. http://science.science mag.org/. Last accessed 31/07/2020

Rodríguez A, Canals RM, Plaixats J, Albanell E, Debouk H, Garcia-Pausas J, San Emeterio L, Ribas À, Jimenez JJ, Sebastià MT. 2020. Interactions between biogeochemical and management factors explain soil organic carbon in Pyrenean grasslands. Biogeosciences 17:6033-50. https://bg.copernicus. org/articles/17/6033/2020/. Last accessed 01/05/2020 
Rodríguez A, de Lamo X, Sebastià MT. 2018. Interactions between global change components drive plant species richness patterns within communities in mountain grasslands independently of topography. Collins B, editor. J Veg Sci 29:102939. https://doi.org/10.1111/jvs.12683. Last accessed 16/02/ 2019

Root RB. 1967. The Niche Exploitation Pattern of the Blue-Gray Gnatcatcher. Ecol Monogr 37:317-50. https://doi.org/10.230 7/1942327. Last accessed 30/04/2020

Van Ruijven J, Berendse F. 2005. Diversity-productivity relationships: Initial effects, long-term patterns, and underlying mechanisms. Proc Natl Acad Sci U S A 102:695-700.

Scherer-Lorenzen M, Palmborg C, Prinz A, Schulze ED. 2003. The role of plant diversity and composition for nitrate leaching in grasslands. Ecology 84:1539-52. https://doi.org/10.1890/0 012-9658\%282003\%29084\%5B 1539\%3ATROPDA \% 5D2.0. CO\%3B2?journalCode $=$ ecol. Last accessed 20/08/2019

Schipanski ME, Drinkwater LE. 2012. Nitrogen fixation in annual and perennial legume-grass mixtures across a fertility gradient. Plant Soil 357:147-59. https://doi.org/10.1007/s111 04-012-1137-3. Last accessed 31/08/2019

Schlesinger WH. 1977. Carbon Balance in Terrestrial Detritus. Annu Rev Ecol Syst 8:51-81. https://doi.org/10.1146/annure v.es.08.110177.000411. Last accessed 07/08/2019

Schmid B, Weisser WW, Schumacher J, Roscher C, Schulze ED, Wilcke W, Baade J, Gleixner G. 2004. The role of biodiversity for element cycling and trophic interactions: an experimental approach in a grassland community. Basic Appl Ecol 5:107-121.

Sebastiá M-T. 2004. Role of topography and soils in grassland structuring at the landscape and community scales. Basic Appl Ecol 5:331-46. https://www.sciencedirect.com/science/articl e/pii/S1439179104000088. Last accessed 16/02/2019

Sebastià M-T, de Bello F, Puig L, Taull M. 2008. Grazing as a factor structuring grasslands in the Pyrenees. Appl Veg Sci 11:215-222. https://doi.org/10.3170/2008-7-18358.

Sebastiá M-T, Sebastià M-T. 2004. Role of topography and soils in grassland structuring at the landscape and community scales. Basic Appl Ecol 5:331-46. https://www.sciencedirect.c om/science/article/pii/S1439179104000088. Last accessed 16/ $02 / 2019$

Sebastià MT. 2007. Plant guilds drive biomass response to global warming and water availability in subalpine grassland. J Appl Ecol 44:158-167.

Sebastià MT, Puig L. 2008. Complex vegetation responses to soil disturbances in mountain grassland. Plant Ecol 199:77-88.

Sollenberger LE, Kohmann MM, Dubeux JCB, Silveira ML. 2019. Grassland management affects delivery of regulating and supporting ecosystem services. Crop Sci 59:441-59. http s://dl.sciencesocieties.org/publications/cs/abstracts/59/2/441

Solly EF, Schöning I, Boch S, Kandeler E, Marhan S, Michalzik B, Müller J, Zscheischler J, Trumbore SE, Schrumpf M. 2014. Factors controlling decomposition rates of fine root litter in temperate forests and grasslands. Plant Soil 382:203-218.

Spehn EM, Scherer-Lorenzen M, Schmid B, Hector A, Caldeira MC, Dimitrakopoulos PG, Finn JA, Jumpponen A, O'Donnovan G, Pereira JS, Schulze ED, Troumbis AY, Körner C. 2002. The role of legumes as a component of biodiversity in a cross-European study of grassland biomass nitrogen. Oikos 98:205-18. https://doi.org/10.1034/j.1600-0706.2002.980203 .x. Last accessed 30/08/2019

Spohn M, Pötsch EM, Eichorst SA, Woebken D, Wanek W, Richter A. 2016. Soil microbial carbon use efficiency and biomass turnover in a long-term fertilization experiment in a temperate grassland. Soil Biol Biochem 97:168-175. https://d oi.org/10.1016/j.soilbio.2016.03.008.

Steinbeiss S, Beßler H, Engels C, Temperton VM, Buchmann N, Roscher C, Kreutziger Y, Baade J, Habekost M, Gleixner G. 2008. Plant diversity positively affects short-term soil carbon storage in experimental grasslands. Glob Chang Biol 14:293749. https://doi.org/10.1111/j.1365-2486.2008.01697.x. Last accessed 30/08/2019

Steneck RS. 2001. Functional Groups. Encycl Biodivers:609-23. https://www.sciencedirect.com/science/article/pii/B97801238 47195001805?via\%3Dihub. Last accessed 22/07/2019

Suter M, Connolly J, Finn JA, Loges R, Kirwan L, Sebastià MT, Lüscher A. 2015. Nitrogen yield advantage from grass-legume mixtures is robust over a wide range of legume proportions and environmental conditions. Glob Chang Biol 21:2424-2438.

Suttie JM, Reynolds SG, Batello C. 2005. Grasslands of the world. Food \& Agriculture Org.

Symonds MRE, Moussalli A. 2011. A brief guide to model selection, multimodel inference and model averaging in behavioural ecology using Akaike's information criterion. Behav Ecol Sociobiol 65:13-21.

Villéger S, Mason NWH, Mouillot D. 2008. New multidimensional functional diversity indices for a multifaceted framework in functional ecology. Ecology 89:2290-301. https://doi. org/10.1890/07-1206.1. Last accessed 14/06/2019

Wardle DA. 2016. Do experiments exploring plant diversityecosystem functioning relationships inform how biodiversity loss impacts natural ecosystems? Palmer M, editor. J Veg Sci 27:64653. https://doi.org/10.1111/jvs.12399. Last accessed 05/09/2019

Wayne PM, Bazzaz FA. 1991. Assessing diversity in plant communities: The importance of within-species variation. Trends Ecol Evol 6:400-404.

Wu GL, Liu Y, Tian FP, Shi ZH. 2017. Legumes Functional Group Promotes Soil Organic Carbon and Nitrogen Storage by Increasing Plant Diversity. L Degrad Dev 28:1336-44. https://d oi.org/10.1002/ldr.2570. Last accessed 22/08/2019

Yuan ZQ, Jiang XJ. 2021. Vegetation and soil covariation, not grazing exclusion, control soil organic carbon and nitrogen in density fractions of alpine meadows in a Tibetan permafrost region. Catena 196:104832.

Yuan ZY, Jiao F, Shi XR, Sardans J, Maestre FT, Delgado-Baquerizo M, Reich PB, Peñuelas J. 2017. Experimental and observational studies find contrasting responses of soil nutrients to climate change. Elife 6.

Zanetti S, Hartwig UA, Van Kessel C, Lüscher A, Hebeisen T, Frehner M, Fischer BU, Hendrey GR, Blum H, Nösberger J. 1997. Does nitrogen nutrition restrict the $\mathrm{CO} 2$ response of fertile grassland lacking legumes? Oecologia 112:17-25. https://doi.or $\mathrm{g} / 10.1007 / \mathrm{s} 004420050278$. Last accessed 30/08/2019

Zeng C, Wu J, Zhang X. 2015. Effects of grazing on above-vs. below-ground biomass allocation of alpine grasslands on the northern tibetan plateau. PLoS One 10:1-15. https://doi.org/ 10.1371/journal.pone.0135173.

Zhao J, Wang X, Wang X, Fu S. 2014. Legume-soil interactions: legume addition enhances the complexity of the soil food web. Plant Soil 385:273-86. https://doi.org/10.1007/s11104014-2234-2. Last accessed 23/08/2019

Zhou X, Wang Y, Zhang P, Guo Z, Chu C, Du G. 2016. The effects of fertilization on the trait-abundance relationships in a Tibetan alpine meadow community. J Plant Ecol 9:144-52. https://doi.org/ 10.1093/jpe/rtv043. Last accessed 11/04/2019 